\title{
Patriarchy Rejected: A Feminist Reading in Some Selected Poems by Adrienne Rich and Fatima Naoot
}

\author{
Usama Raslan ${ }^{1}$ \\ ${ }^{1}$ Department of English, Higher Institute for Specific Studies, Giza, Egypt \\ Correspondence: Usama Raslan, Higher Institute for Specific Studies, Haram St, Nazlat al-Batran Giza, Egypt. \\ E-mail: raslanndr@gmail.com
}

Received: November 6, 2018 Accepted: November 28, 2018 Online Published: January 24, 2019

doi:10.5539/ells.v9n1p1 URL: https://doi.org/10.5539/ells.v9n1p1

\begin{abstract}
The present paper offers a comparative feminist reading of the American poet Adrienne Rich and the Egyptian poet Fatima Naoot. It aims at analyzing both Rich's and Naoot's poetry in terms of feminist criticism demonstrated particularly in Beauvoir and Millett's theory of patriarchy. The collections from which the poems under study are selected are Rich's The Fact of a Doorframe: Poems Selected and New, 1950-1984 (2002), and Naoot's A Bottle of Glue (2007). The selected poems are Rich's "Aunt Jennifer's Tigers", "An Unsaid Word", and "Power", and Naoot's "The Cock's Crest", "A Goose", and "Isis". The analysis of these poems motivates one to infer three essential points regarding the poetic achievement of both poets. First, patriarchy is a male programming engineered by the male to subdue and decentralize the female by treating the latter as if she were a sexed being, or rather the inessential other. Second, this inferior position of woman motivates Rich and Naoot to incorporate Beauvoir and Millett's theory of patriarchy into their verse. In order to achieve this objective, both poets set up a poetic vision in terms of which they portray how patriarch marginalizes and subordinates woman. Lastly, the close reading to the selected pieces denotes that they rotate around the systematized oppression of women. Such is the common theme of Rich and Naoot's verse.
\end{abstract}

Keywords: beauvoir, female, feminism, male, Millett, Naoot, patriarchy, Rich

\section{Introduction}

This paper attempts a comparative feminist study of the American essayist, critic and poet, Adrienne Rich (1929-2012) and the Egyptian activist, essayist, translator, critic and poet, Fatima Naoot (1964- ). It aims at analyzing both Rich's and Naoot's poetry in terms of feminist criticism demonstrated particularly in Beauvoir and Millett's theory of patriarchy. The collections from which the poems under study are selected are Rich's The Fact of a Doorframe: Poems Selected and New, 1950-1984 (2002), and Naoot's Qarorart Samgh (2007 [translated into English by Sayed Gouda as A Bottle of Glue). The analysis will contend that feminism is an interdisciplinary critical theory that "examines the ways in which literature... reinforces or undermines the economic, political, social, and psychological oppression of women" (Tyson, 2006, p. 83). This oppression proceeds from the patriarchal belief that while the male is the essential subject, the female is the inessential other that should be treated as a submissive follower.

Hence, the very objective of the study at hand is to argue that the subordination of women is the leitmotif in Rich and Naoot's poems. In order to depict such a dominant motif, i.e., how women suffer from patriarchal segregation, both female poets compose a poetic vision that brings into prominence the power-structured relationships designed by the male to create an imbalance of power that subordinates the female. Even though a number of critical studies have examined the poetic output of both Rich and Naoot in the light of feminism, no current academic study has combined the poetic achievement of both writers together. However, the present study compares Rich's poetic product with that of Naoot within a feminist context in the hope of illustrating how each poet explores the reasons behind the birth of patriarchy as well as motivating women to stand against patriarchal programming, which seems to have marginalized the female since the beginning of human history.

Patriarchy, as this paper argues, is but a male programming in terms of which men invent a sexed ideology that reinforces "a system of male domination and female subordination" (Bryson, 2003, p. 169). This system implies that women are maltreated in all civilizations as "a sexed being" or rather "an accidental being" (Beauvoir, 2010, p. 25), responsible for unleashing the evil that destroys human existence. Although Rich and Naoot belong to 
two completely different cultures, a close reading of their poetry highlights the social system through which patriarchy dehumanizes women by pressurizing them to accept male supremacy as the eternal law of life. That is to say, the very aim of patriarchy is to empower the situation of man as a master and degrade that of the woman as a slave. Such is the leitmotif that forms the thematic structure of Rich's and Naoot's poetic achievement.

Both Rich and Naoot, to use Millett's words, employ their poetry to show how patriarchy divides society into two main classes according to gender: "the master class" and "an underclass" (1968, p. 366). While the former is represented by men, the latter is so done by women. This division has always urged feminist critics to confirm that the relationship between the male and female should be examined in the shade of "master-slave relation" (Beauvoir, 2010, p. 29). Such is the patriarchal agenda which has driven Rich and Naoot to point out how patriarchy does not only minimize the status of women, but also instill into culture that they are not humans. Rather, they are slaves. That is why both poets advocate a poetic strategy, which criticizes the "power-structured relationships" (Millett, 2000, p. 24), and the idea of "birthright priority" (Millett, 2000, p. 24), mainly because they sustain the conception of the female as "an inessential being" (Beauvoir, 2010, p. 43). This feminist criterion is best achieved in Rich's and Naoot's poetry.

\section{Patriarchy in Rich}

When searching for a poetic link between Rich and Naoot, one finds out that the close connection between both poets is grounded in exploring the power-structured relationships by which the male subordinates the female. This subordination is best achieved in Rich's and Naoot's poetry, which aim at bridging the gap between womanhood and male power. In this regard, many critics confirm that Rich is a feminist artist because her poems deal not only with "the common oppression of women" (Rich, 1986, p. 210), but also with the patriarchal programming, that keeps women "under the thumb of men" (Jayasudha, 2016, p. 50). In her book, Blood, Bread, and Poetry: Selected Prose, 1979-1986 (1986), Rich outlines the negative consequences of patriarchy. She argues that the power wielded by men over women flows from patriarchy that legalizes all forms of exploitation and "illegitimate control" of the female consciousness. Because patriarchy sets up a male framework that ideologizes all forms of domination and subjugation, Rich uses her poetry to discover the "single causes" that makes man construct a patriarchal methodology for undermining the status of women in culture. This male attitude results from the notion that patriarchy has a hidden agenda, or rather an ideology that privileges one race (the male) over the other (the female). In so doing, patriarchy is a remarkable sign of the fall and decline of human civilization - for it causes "a tangle of oppressions" that ignores women's equality with men throughout history. The only solution available for women to improve the conditions of their existence is to champion their emancipation from man's power-hungry:

The power men everywhere wield over women... has become a model for every other form of exploitation and illegitimate control... I would go so far as to say that even before slavery or class domination existed, men built an approach to women that would serve one day to introduce differences among us all... Patriarchy exists nowhere in a pure state; we are the latest to set foot in a tangle of oppressions grown up and around each other for centuries. (pp. 217-218)

\section{Patriarchy in Naoot}

Unlike Rich who asserts the feminist aspect of her poetry, Naoot refuses what literary critics categorize as feminine and masculine writings. Her refusal springs from the belief that if the critics classify literary discourse on the ground of sex, they should apply this classification to all forms of art including music and sculpture. To support her argument, she elucidates that "woman, like man, is a human being who relies heavily on the art of creative writing in the hope of voicing the painful experience, which befalls her. Despite that, the mentality of woman is more organized than that of man; therefore, woman's approach to reality is more authentic and accurate than that of man" (Note 1) (2003, p. 17 [trans. mine]). However, Naoot is conceived to be a feminist poet who challenges the concept of patriarchy in the Egyptian society.

In her book, Al-Mughanni wa Alhakka' (2009 [A Critical Perspective on the Art of Poetry and Novel]), Naoot sheds light on the power-structured relationships invented by patriarchy. She spells out that although woman is man's artistic source of inspiration, the male artist has a fervent desire to cage her within the bonds of patriarchy. In order to fulfill this goal, the male devises a power strategy that seeks to tame and train woman on holding that the female segregation is the eternal law of existence. Such a male ideology has a two-edged function: first to instigate women to accept their subordination and second to make them appear as if they were the inessential other that has no political or economic identity outside the gender oppression. While patriarchy bestows an irresistible power on man, it implants into woman the doctrine that the only solution for her to feel existence is to resist man's power: 
Throughout history, the prominent goal of man is to subordinate woman.... In fact, man exerts himself to subdue the woman for two reasons: first to maintain his fabricated existence as a master and second to domesticate woman on accepting her function as a slave that ought to obey the master. This male programming can be referred back to the saying that 'too many cooks spoil the soup'. For all that, woman is a brave fighter who has a dogged determination to defy man's patriarchal agenda that gains its power from a sacred male decree, which is no longer open to any female appeal. (Note 2) (p. 145 [trans. mine])

\section{Beauvoir's Concept of Patriarchy}

In order to appreciate the feminist tendency of Rich's and Naoot's poetry, one should regard it in the light of the aesthetic achievement of Simone de Beauvoir and Kate Millett. Beauvoir (1908-1986) is a French novelist, philosopher, political activist, and feminist theorist. Motivated by Pythagoras' statement that "there is a good principle that created order, light and man and a bad principle that created chaos, darkness and woman" (Beauvoir, 2010, p. 114), she discusses the reasons and factors that led male thinkers to associate women with darkness and men with light. Her The Second Sex (2010), a groundbreaking book that "has been called a feminist bible" (Thurman, 2010, p. 11), provides a starting point for the second wave of feminist criticism. In it, she introduces the cultural climate that gives rise to the birth of patriarchy - the time in which humankind writes "its mythology and laws". During that time, the male set up the codes of patriarchy that placed the female in "a subordinate position," simply because men are the makers of human history. Although men were benevolent with women, they are interested in legalizing women's oppression, as well as treating women as if they were unclean creatures. To support such an argument, Beauvoir cites an example of two female figures around which theory of patriarchy is established: Eve and Pandora. While Eve created by God to be Adam's partner, patriarchy deceives humans into holding that she is the root cause for the suffering of humanity. Pandora, a female mythic figure invented by the pagan gods, is responsible for unleashing the evil that deforms human existence. These two examples illustrate the reasons why women are identified with evil, passivity, and disorder, whereas men are associated with activity, goodness, and order. In short, women ought to submit to the patriarchal ideology; otherwise, they will never be clarified of their "original strain":

By the time humankind reaches the stage of writing its mythology and laws, patriarchy is definitively established: it is males who write the codes. It is natural for them to give woman a subordinate situation.... Eve, given to Adam to be his companion, lost humankind; to punish men, the pagan gods invent women, and Pandora, the firstborn of these female creatures, is the one who unleashes all the evil that humanity endures. (p. 114)

Patriarchy, therefore, plays up the notion that the female is merely a passive other that ought to receive her subordination with open arms. This subordination implies that the relationship between man and woman is not symmetrical, since patriarchy sublimates the status of man and undermines that of woman: while "man represents both the positive and the neutral aspects of humanity, woman represents only the negative" (Heinama, 2005 , p. 124). The degradation of women motivates men to formalize the belief that woman is "an incomplete man", or rather "an accidental being" whose existence has no meaning outside the limits of the male authority. Such is the patriarchal programming that forces women to avoid thinking of existence away from the power of man because existence is a male-dominated phenomenon. That is why the inferiority of women can be referred back to patriarchy, which compels men to believe that woman is "a sexed being" that has no identity outside the oppressive power of man. While man is the essential subject, woman is the inessential other. Beauvoir puts this idea as follows:

Man thinks himself without woman. Woman does not think herself without man. And she is nothing other than what man decides; she is thus called "the sex", meaning that the male sees her essentially as a sexed being; for him she is sex, so she is it in the absolute. She is determined and differentiated in relation to man, while he is not in relation to her; she is the inessential in front of the essential. He is the Subject; he is the Absolute. She is the Other. (2010, pp. 25-26)

\section{Millett's Concept of Patriarchy}

The portrait of woman as a sexed being formulates the central thesis of patriarchy. It also paves the way for the American feminist writer, activist, and sculptor Kate Millett (1934-2017) to compose a new theory of patriarchal power. In her article, "Sexual Politics: A Manifesto for Revolution" (1968), she calls upon women to revolt against all forms of oppression imposed on them by patriarchal ideology. She argues that the relationship between men and women is a political one. Her argument can be referred back to the view that all human civilizations represent a patriarchal agenda in terms of which men engineer an ideology that guarantee the exploitation and subjugation of women. Not only does this male programming deprive women of enjoying any 
"equality of status", but it also prevents them from being recognized as "human beings". The dehumanization of women results from the patriarchal power of men that deepens women's oppressive position, mainly because patriarchy brings on a systematized male programming. Not only does this patriarchal agenda subdue the female identity, but it also dismisses the female from the social order for their sex, not gender:

When one group rules another, the relationship between the two is political. When such an arrangement is carried out over a long period of time it develops an ideology.... Throughout history women... are represented in no positions of power, and authority is forbidden them. The image of women fostered by cultural media, high and low, then and now, is a marginal and demeaning existence, and one outside the human condition - which is defined as the prerogative of man, the male. (pp. 365-366)

Having articulated a theory of patriarchy, Millett brings into play the notion that patriarchy is the "primary system of political oppression" (Rogan, 2002, p. 45). This definition explains how men adopt different power structures with a view to conditioning women to accept their segregation with open arms. In her significant book, Sexual Politics (2000), Millett draws an analogy between sex (gender) and politics. In it, she contends that the relationship between sexes can be analyzed in a political light. To maintain this contention, she states that the term politics refers to "power-structured relationships" by which the male subordinates the female. While sex is "a status category" that has political implications, politics is a descriptive term used by feminist critics to outline the status relationship between different sexes. This denotes that literary theory is in need of a new concept of politics, which is mainly concerned with investigating power relationships that lead cultural media to privilege masculinity over femininity. In order to accomplish this objective, feminist discourse should search for a new definition of politics and sex through which women can produce non-patriarchal ways of thinking, or rather a theory of patriarchy in terms of which politics and sex can be redefined with an eye to redressing the imbalance between men and women:

The term "politics" shall refer to power-structured relationships, arrangements whereby one group of persons is controlled by another.... The word "politics" is enlisted here when speaking of the sexes primarily because such a word is eminently useful in outlining... a more relevant psychology and philosophy of power relationships beyond the simple conceptual framework provided by our traditional formal politics. (pp. 23-24)

\section{Discussion}

Beauvoir's conception of woman as the inessential other along with Millett's postulation of power-structured relationships is best translated in Rich's "Aunt Jennifer's Tigers", "An Unsaid Word" and "Power" and Naoot's "The Cock's Crest", "A Goose" and "Isis". In her attempt to portray these relationships, Rich formulates a poetic vision that aims "to write directly and overtly as a woman, out of a woman's body and experience, to take women's experience seriously" (Rich, 1986, p. 56). In "Aunt Jennifer's Tigers", Rich addresses the question of male-female relationships - the segregation that hangs over woman through marriage tradition. To fulfill this objective, Rich composes the poem "in a third-person narrative which sets herself apart from Aunt Jennifer" (Jayasudha, 2016, p. 50). In so doing, she imbues her lines with an aesthetic power that helps to unfold the negative consequences of patriarchy on the psyche of women by using Aunt Jennifer's tapestry of tigers as a means for tolling the bells for the masculine mind to stop subjugating the feminine mentality.

In order to show how the male segregates the female, "Aunt Jennifer's Tigers" deals with describing the professional magnificent way in which Aunt Jennifer utilizes her artistic talent to weave a portrait of tigers on a piece of cloth. What she embroiders is not a traditional tapestry. Rather, it is a "bright topaz" in terms of which Rich investigates "the tension between the protagonist's creativity and her social circumstances" (Soghra \& Pourgiv, 2016, p. 74). This topaz, which reflects the purity of "a world of green", or rather the social state of women before the advent of patriarchy, implies that Aunt Jennifer's embroidery of tigers is no more than a feminist mechanism for resisting male hegemony. This assessment can be referred back to the notion that the women/tigers "do not fear the men beneath the tree" so that they can march on the screen with heavy hearts without taking into account the aggressive nature of patriarchal order:

Aunt Jennifer's tigers prance across a screen,

Bright topaz denizens of a world of green.

They do not fear the men beneath the tree;

They pace in sleek chivalric certainty. (Rich, 2002, p. 4)

Despite the "chivalric certainty" in which the tigers move, they flutter because of the subjugation to which Aunt Jennifer is conditioned. This fluttering, which flows from the marriage responsibilities, paves the way for Aunt 
Jennifer to understand "her full potential as a woman in a male-dominated society" (Jayasudha, 2016, p. 49). The reasons for this critical situation can be traced back to the patriarchal memories of the past that make the Aunt realize that she will never shed "the massive weight of Uncle's wedding band"-for this memory is the primary reason behind her inability to move her hand naturally. The memory of her husband acts as a symbol of patriarchal authority that negates women any prerogative even if it is an imaginary one like that of the tigers. Not only does this programming weigh Aunt Jennifer with social anxiety, tension, and isolation, but it also motivates her to get the feeling that patriarchy is responsible for victimizing womanhood. For all that, the tigers (women) should "go on prancing, proud and unafraid":

Aunt Jennifer's fingers fluttering through her wool

Find even the ivory needle hard to pull.

The massive weight of Uncle's wedding band

Sits heavily upon Aunt Jennifer's hand.

When Aunt is dead, her terrified hands will lie

Still ringed with ordeals she was mastered by. (Rich, 2002, p. 4)

The ordeals that obsessed Aunt Jennifer reflect the negative consequences of patriarchy on the existence of the Aunt. To convey such dire consequences, the poet ends the poem with the notion that the male hegemony is so destructive that when the Aunt passed away, her subordination will never fade away because of the massive ordeals that "mastered" her. Indeed, the verb "mastered" is profoundly evocative of the segregation that befalls the Aunt, mainly because it "illustrates the mastery or domination of patriarchy over a woman" (Soghra \& Pourgiv, 2016, p. 74) that has no option but to think of her relationship with man in terms of what Beauvoir calls "master-slave relation" (2010, p. 29). While the Uncle is the master, Aunt Jennifer is the slave who suffers greatly from the massive power of the uncle. This power, to cite Beauvoir, puts the Aunt at "a considerable disadvantage. Even when her rights are recognized abstractly, long-standing habit" (2010, p. 29) forces her to make herself into "a thing" (2010, p. 30), or rather an animal. This conception explains the reasons why Aunt Jennifer associates herself and the conditions of women with the tigers. In spite of the male oppression, the tigers (women) are determined on prancing across the screen with a view to resisting the male programming.

Aunt Jennifer's considerable disadvantage is echoed through Naoot's "Cock's Crest" in which patriarchy forces the protagonist to think of herself in terms of animal imagery. Like Rich, Naoot draws on the third-person narrator in order to reveal the painful experience of the female in a male-oriented culture. This assessment implies that Naoot's poem introduces a battle cry for all women to resist their inferior position as submissive subordinates to man. Such inferiority motivates Naoot to envision existence devoid of the male supremacy by asking women to isolate themselves from man's power-structured relationships. In "Cock's Crest", Naoot "provides the readers with an untraditional conception of women's alienation from the male-dominated society, or rather the female solitude where women can feel no pains or tensions. It is a steady loneliness that will never be disintegrated by the patriarchal agenda which sustains the belief that a 'shadow of a man is better than a shadow of a wall"' (Note 3) (Muhsen, 2008, p. 12 [trans. mine]).

Hence, the speaker attempts from the very beginning of "Cock's Crest" to disempower the position of man by depicting a world devoid of the male hegemony, the power that not only dehumanize women's existence, but also pollutes it. She numerates the positive consequences of removing the traces of man from the domains of female memory by repeating a crucial central phrase throughout the whole poem: "How nice". The repetitive use of such a phrase denotes that "the feminist experience draws extensively on manipulating the aesthetic space created by the absence of man. This space endows woman with a chance to imagine a recovering patriarchal society where woman never fears of the male subjugation" (Note 4) (Abd-al-Salam, 2008, p. 7 [trans. mine]). In so doing, woman can lie down in peace stretching her arms. This physical comfort brings out a psychological relief by which the poet does not only free herself from the systematized marginalization of man, but also reaches the bliss of solitude by touching "the ceiling corners" and clasping her "hands under" her "chin" as if it were "a cat". The more the woman uses her vivid poetic imagination, the more man's power is disappeared. This disappearance leads the speaker to exceed the limits of imagination by confirming that she is not a cat. Rather, she is "a butterfly" that overcomes the patriarchal ideology of man who demonstrates his best to tie her down, but in vain: 
How nice to lie down

And stretch your arms

And touch the ceiling corners

Or to clasp your hands under your chin like a cat

Stretching its back.

How nice to unfold yourself like a butterfly. (Naoot, 2007, p. 26)

By urging women to unfold themselves "like a butterfly", Naoot produces a feminist identity that does not only blow up the bonds of women's slavery, but also redress the imbalance of the male-female power relationships. In order to carry out such an aim, "she sustains the advent of a revolutionary feminist persona that utilizes the art of imagination, deep meditation, and irony with a view to challenging patriarchy without sacrificing the aesthetic dimension of the feminist voice in the poem" (Note 5) (Abd-al-Salam, 2008, p. 7 [trans. mine]). That is why the poet goes on describing the innumerable benefits of wiping out man's authority from existence because it epitomizes the root of women's oppression. Her description revolves around the feminist premise that the abolition of this authority will certainly provide any woman with a license to "breath [sic] all the air of the room/Alone." With the end of man's patriarchal power, woman can breathe easily - for the male oppression is no longer existed. However, the poet asks women to take a deep breath as most they can before the return of man, or rather the "cock's crest", insomuch as the cock will swallow and destroy women's fabricated existence because of his/its constant coughing. In so doing, women can feel existence as humans, no slaves, by transforming the male prerogatives into "a library". This transformation enables women to regain their status category as active participant in society. Such is the female due right which patriarchy ignores from the dawn of civilization:

How nice

To breath all the air of the room

Alone

Before it is swollen by coughing

Or polluted

By a cock's crest.

How nice to turn half the bed

Into a library. (Naoot, 2007, p. 26)

Upon turning half of the bed into a library, the female does not only reject the male's supremacy, but also articulates a theory of what Naoot calls "the female matriarchy" (Note 6) (Naoot, 2008b, p. 8 [trans. mine]). In it, the woman enjoys a sense of power that makes her the dominant one, not the dominated. This explains the reasons why Naoot's "Cock's Crest" is electrified with vivid images in which the poet likens women's emancipation to that of the cat and butterfly. These poetic devices lend the speaker a hand to examine the power relationships that bring out the male domination and female subordination. The examination of such relations, to quote Millett, indicates that the subjugation and segregation experienced by women can be traced back to "the birthright priority" (2000, p. 25) by which the males do not only rule the female, but also humiliate them. Through this patriarchal programming, "a most ingenious form of 'interior colonization' has been achieved" (2000, p. 26). That is why Naoot's cock's crest is a symbol for the male interior colonization, which tends to be "sturdier than any form of segregation, and more rigorous than any class stratification, more uniform, certainly more enduring" (2000, p. 26).

In "An Unsaid Word", Rich addresses the patriarchal view that silence begets "pure acts" (Valéry, as cited in Beauvoir, 2010, p. 232). Such acts refer one to the major motif in terms of which Rich explores the fatal impact of man's hegemony on the women's fabricated existence, which brings on the female dead silence. Not only does Rich illustrate the disastrous consequences of silence on women, but she also searches for the reasons behind the emergence of this silence. In so doing, the poet introduces the patriarchal arrangements in terms of which man deploys the institution of marriage to control woman by forcing her to live within an "estranged intensity". To reveal such intensity, the poet represents the dilemma of an unnamed woman who seeks to grasp the difficult "lessons of passivity and silence" (Stein, 2017, p. 25) so that she will not only endure, but also prevail as a woman in a male-oriented culture. Her attempt to survive urges Rich to level a feminist strong criticism at patriarchal values that decentralize women's prerogative within society. 
Accordingly, "An Unsaid Word", a one-stanza poem, criticizes the heroine of the poem for her submission to the patriarchal programming, the male power that marginalizes her existence. Although the woman possesses the power to defend herself, she accepts the male subordination of the husband that causes her to feel "estranged intensity". Rather than challenge this power, the woman waits for the arrival of her husband, mainly because she will never be able to live without the help of man. She also "did not possess her own being; she depended upon man to validate her partial existence. She thought of herself as a burden to man" (Hassan, Kaur, \& Mani, 2016, p. 59) whose "mind forages alone." While women's identity draws greatly on man who "keeps her peace," woman provides man with a sort of freedom that degrades woman's situation. It also instigates woman to receive her segregation with open arms. By caging woman within the bonds of marriage, man imposes his patriarchal agenda as a master on woman. This explains why the woman has nothing to do, except "waiting and weeping for the absence of the master of the house" (Hassan, Kaur, \& Mani, 2016, p. 58), mainly because patriarchy makes her hold that she is no more than a chattel owned by man. This is the most painful experience that any female can learn:

She who has power to call her man

From that estranged intensity

Where his mind forages alone,

Yet keeps her peace and leaves him free,

And when his thoughts to her return

Stands where he left her, still his own,

Knows this the hardest thing to learn. (Rich, 2002, p. 5)

A feminist reading of "An Unsaid Word" shows that the poem represents a battle between two completely different voices: "the dominant and the dominated" (Hassan, Kaur, \& Mani, 2016, p. 59). Whereas the former stands for the male power, the latter refers to the female submission. This assessment urges one to figure out that the whole poem is an unconditional surrender through which the woman (dominated) admits her resounding defeat in fighting the patriarchal power of the husband (the dominant). Quoting James Scott's comment on power relations, one can estimate that the defeat of the woman results from the maxim that the husband (the powerful) is keen on "keeping up the appearances appropriate to" (1990, p. 70) his power strategy. On the other hand, the woman (the subordinate) has no alternative but to "help sustain those appearances or, at least, not openly to contradict them" $(1990$, p. 70). If this statement is taken a step further, one can conclude that the man of "An Unsaid Word" uses his power to convince the woman that she ought to obey her master-for resistance is "the hardest thing to learn". In recognizing the impossibility of escaping man's power, the woman does not only sacrifice her existence for satisfying man's desire for mastery, but also accepts to be the inessential other that has no identity outside the patriarchal world.

The female voice projected in Rich's "An Unsaid Word" is best illustrated in Naoot's "A Goose" in which she details the violence and tragedy that hang over femininity in a male-oriented culture. Like Rich's poem, Naoot's "A Goose", a one-stanza poem, portrays how man uses his patriarchal power to prevent woman from erasing the reasons behind her subordination. Thus, the thematic structure of the poem highlights the hidden motives that compel the truck driver/the husband to behead the goose/his wife. His violent action asserts that man interacts with woman as if she were a sexual object that ought to satisfy the desires of her master by being a slave to patriarchal agenda. Not only does the husband oppress his wife (the goose), but he also "engineers a conception of her as a mindless creature- for mind encourages her to argue with him. Such a male attitude brings into prominence the belief that the track driver suffers from the inferiority complex" (Note 7) (Muhsen, 2008, p. 12 [trans. mine]). This inferiority forces the fictional protagonist of Rich's "An Unsaid Word" and Naoot's "A Goose" to sit in a dead silence, without trying to defend their feminist identity against the male exploitation.

Naoot's "A Goose", therefore, begins with sheer contradictory lines. In them, the speaker contends that even though "the truck driver/was nice" $(2007$, p. 10) to the goose, he was so heartless that he accidentally slaughters her. Not only does this violent attitude reveal the dangerous aspect of patriarchal agenda, but it also urges one to sum up that Naoot uses the tragedy that the goose undergoes to set up an argumentative strategy. This poetic strategy helps her "penetrate deeply into the painful experience that obsessed the feminist existence- the marginalization inflicted upon women in patriarchal male-dominated societies" (Note 8) (Muhsen, 2008, p. 12 [trans. mine]). In this respect, patriarchal power forces the truck driver to pretend that he is on good terms with his wife (the goose). His false pretension encourages him to give up the idea of beheading the goose "for three months/And twenty days/And five hours". For all that, he is bent on killing the goose because of her sexual 
maturation that threatens his supremacy by sexing him up. Hardly does he discover this maturation when he makes up his mind to cut her throat insomuch as she leaves the living room "naked of feathers" without having a license from the man. In return for this vehement behavior, the woman shows no resistance. Rather, she, like Rich's heroine, yields submissively to her fate without bleeding, nor crying out in pain:

The truck driver

Was nice

When he resisted slaughtering the goose

But he did it

When he noticed her leaving the living room naked of feathers

When he cut her throat

She looked at him

And didn't shed

A drop of blood! (Naoot, 2007, p. 10)

When the goose/woman is killed, she does not shed a drop of blood. Rather, she stays silent. Her silence illustrates the defence mechanisms in terms of which the female can revolt against the male oppression. It also compels one to elicit that "the goose/woman succeeds to overcome the act of slaughtering as well as the patriarchal violence threatening the female identity" (Note 9) (Abd-al-Salam, 2007, p. 5 [trans. mine]). Whereas the truck driver adopts violence, the woman draws on silence as a powerful weapon in challenging men's subjugation. This different power mechanisms, to deploy Millett's terms, can be referred back to the fact that power-structured relationships can be supported "either through consent or imposed through violence" (2000, p. 26). Such a statement explains why the truck driver relies on violence as a means for bestowing "superior status" (2000, p. 26) on his fabricated existence and "inferior" one (2000, p. 26) on that of woman. Within this in mind, one can figure out that Naoot dramatizes the story of the driver and the goose in order to evince that the terms masculine and feminine are but an illusion. This illusion results from "the needs and values of the dominant group and dictated by what its members cherish in themselves and find convenient in subordinates" (2000, p. 26).

In order to show how patriarchy victimizes women, Rich composes "Power". In it, she represents an aesthetic dimension of her poetic vision, which is grounded in rereading the past in the hope of refuting the patriarchal myths, or rather the male ideology that minimizes the situation of women and maximizes that of men. Such is the thematic structure of Rich's "Power". In her enlightening essay, When We Dead Awaken: Writing as Re-Vision (1972), Rich states openly that her poetic vision relies greatly on traveling back in history with a view to grasping the real nature of the conflict between femininity and masculinity. By revisiting the past, not only does she rebut the white mythologies designed by men to degrade women, but she also formulates a critical practice that enables her to examine literary discourse from a new critical perspective. This practice infuses a feminist vision into her poetry that unfolds the conditions in which women are "drenched". Her vision provides her poetry with an aesthetic imagination in terms of which she probes too deeply into the past to answer four feminist questions that help the female build a cultural discourse devoid of patriarchy. First, how women live; second, how they have been living; third, how they have been forced to accept their marginalization; lastly, how they can stand against male hegemony:

Re-vision - the act of looking back, of seeing with fresh eyes, of entering an old text from a new critical direction... is an act of survival. Until we can understand the assumptions in which we are drenched we cannot know ourselves.... A radical critique of literature, feminist in its impulse, would take the work first of all as a clue to how we live, how we have been living, how we have been led to imagine ourselves. (pp. 18-19)

The answer to the aforementioned feminist questions is best achieved in Rich's "Power", which is perceived to be an ode to the female French scientist Marie Curie (1867-1934) who received the Nobel Prize for two times. This female scientist is "the central figure of the poem" (Prace, 2009, p. 21) because she risked her life not only to satisfy her "hungry for knowledge" (Prace, 2009, p. 21), but also to accomplish the common good for all humanity. That is why the poem consists of four stanzas; each of which describes the tragedy that befalls Curie. It begins with criticizing patriarchy because it excludes from its records the names of many feminist thinkers who live "in the earth-deposits of our history". This exclusion urges the speaker to reconsider the risks and hardships experienced by Curie, one of the leading female figures, who dies of radiation poisoning. Since 
patriarchy constructs solid layers that fold the feminist achievement as well as institutionalize the subjugation of women, the poet makes up her mind to use "a backhoe", not a pen, so as to dig into the human past. By exploring the past, she discovers "one bottle amber", or rather the character of Curie who passed away a hundred years ago. This feminist figure was killed twice: while the former takes place because of her research experiments on radioactivity, the latter is brought on by patriarchy that forgets such a sacrifice on purpose:

Living in the earth-deposits of our history

Today a backhoe divulged out of a crumbling flank of earth

one bottle amber perfect a hundred-year-old

cure for fever or melancholy a tonic

for living on this earth in the winters of this climate. (Rich, 2002, p. 225)

As the poem proceeds, the speaker highlights the reasons that led her to remember Curie. Her very objective is to "reach into the earth for the sources of woman's distinctive power" (Diehl, as cited in Prace, 2009, p. 21). To reveal this power, Rich delves deeply into the past with a view to narrating the story of Curie from A to Z. Even though Curie realizes that her radioactive experiments will cause her "radiation sickness", she is bent on achieving her scientific research for a better life for male and female alike. This tough resolution makes her own body bombard because of the elements she has discovered. For all that, she has a dogged determination to finish her pioneering research on radioactivity as best she can. Never does she take into account the fatal illness and negative consequences of such academic effort. Her attitude makes her lose her sight gradually as well as suffer from "the cracked and suppurating skin of her finger-ends" to the extent that she is unable to hold a pen to write down the results of her experiments. However, male thinkers conceal the sacrifice and accomplishment of Curie who denies her pains and wounds for the sake of humanity. Instead of exhausting her, these wounds empower Curie's position as a recovering patriarchal woman who beats patriarchy—-for her "her wounds came from the same source as her power." Such is the concluding line of the poem:

Today I was reading about Marie Curie:

she must have known she suffered from radiation sickness

her body bombarded for years by the element

She died a famous woman denying

her wounds

denying

her wounds came from the same source as her power. (Rich, 2002, p. 225)

In comparing the first line of "Power" with the last, one can easily find out that while the poem starts with the word "living", it ends with the noun "power". This indicates that any woman should possess a space of power so that she will not merely endure and survive, but also prevail over the male programming. Within this in mind, one can infer that the power relationship between male and female forces woman to believe that she should gain power, otherwise "the cataracts on her eyes", "the cracked and suppurating skin of her finger-ends" will be inflicted upon her fabricated existence. These patriarchal paradigms, to employ Beauvoir's terms, can be referred back to the fact that patriarchy treats woman as "a sexed thing", $(2010$, p. 30) not a human being. This mistreatment leads many feminist critics to differentiate sex from gender. To accomplish this differentiation, they suggest that "gender is an aspect of identity gradually acquired" (Butler, 1986, p. 35) from the interaction between social and biological functions of the female and male.

The analysis of such functions brings into prominence the feminist assumption that "one is not born, but rather becomes, woman" (Beauvoir, 2010, p. 330) because culture maintains the distinction between "the male and the eunuch that is called feminine" (Beauvoir, 2010, p. 330). This criterion denotes that patriarchy, as Tyson observes, utilizes sex to achieve two objectives: first to depict men as "rational strong, protective, and decisive" (2006, p. 85) personae and second, to represent women as submissive weak characters that has no achievements in human history. The unjust representation of female identity implies that patriarchy is but a sexist ideology — for it sustains the creed that "women are innately inferior to men" (2006, p. 85). This inferiority motivates patriarchy to efface deliberately the sacrifice and the scientific accomplishments of great feminist figures like Curie. That is why Rich composes "power" not only to accomplish a form of gender equality, but also to distinguish "between the word sex, which refers to our biological constitution as female or male, and the word gender, which refers to our cultural programming as feminine or masculine" (2006, pp. 85-86). In short, 
the severe wounds that befall Curie stand for the price that any woman should pay for releasing herself from the male oppression.

In line with Rich's attitude, Naoot composes "Isis" in her effort to reject the patriarchal programming that asserts the presence of what Millett calls "passivity, ignorance, docility, virtue, and ineffectuality" (2000, p. 26) in the female character. To achieve this goal, Naoot's poem hinges on a poetic vision that criticizes the male power, simply because it gives rise to the conditions in which women are drenched. Her vision relies heavily on returning to history with a view to rereading and rewriting the mythologies of the past. In her essay, Al-Qna' al-Ramzi Fi A'mal Nawal al-Sadawi (2006 [The Symbolic Meaning of al-Sadawi's Isis]), Naoot introduces her poetic vision. Her vision depends greatly on reworking the mythologies of the past because the mythic discourse outlines the female fervent wish to rebel against patriarchal oppression. Although she insists that each myth should be analyzed in the light of its social and historical context, she argues that the poet has an aesthetic license to reconsider myths according to the significant issues that surround him/her in the present. That is to say, the major task of any feminist poet, to utilize Bloom's terms, is to act as if she were "a strong misreader" who aims to "open received texts to his [her] own sufferings, or what he [she] wants to call the sufferings of history" (2003, p. 4). In short, the rewriting of the mythologies enables woman challenge patriarchal ideologies, as well as restoring their due prerogative as essential other:

It is true that each myth should be examined according to its historical, sociological, and intellectual atmosphere. However, the artist enjoys an aesthetic freedom to deconstruct and reread such myths in the hope of creating a new poetic vision that gains its sensibility from the records of the hidden past.... Of all myths, the poet should pay attention to the Pharaonic, Greek, and the Sumerian mythologies for two reasons: first, they are mainly concerned with universal human values, not gender ones; second, they lay heavy emphasis on the significant problems that hang over woman - for they make woman the main theme of their dramatic actions. (Note 10) (Naoot, 2006, p. 11 [trans. mine])

In "Isis", Naoot travels as far back in history as her feet can carry her to the ancient Egyptian mythology in the hope of reworking the myth of Isis. In fact, this myth narrates the story of Isis, the queen and goddess of Egypt, who is obsessed with grief when Osiris, her husband and son of god, was killed by his brother Seth. Moreover, "his body was mutilated, and that his wife Isis collected his limbs which had been scattered throughout Egypt by Set, or Typhon, and that Osiris by some means obtained a new life in the next world, where he reigned as god and king" (Budge, 1969, p. 126). However, Naoot reworks the Isis myth with a view to showing the destructive power of patriarchy, not for praising Isis for saving Osiris's corpse from the firm grip of Seth. Thus, the principle theme of "Isis" is women's suffering in a male-oriented history that does not only oppress women, but also degrades their status category by concentrating on their role as a wife and mother, not as an active participant in the making of human civilization. Within this in mind, Naoot writes "Isis" to motivate women to break up the male authority that imprisons women within the cages of patriarchy.

Accordingly, "Isis" deals with a detailed sensitive description of Isis as a slim woman who "has a white dove on her head" (Naoot, 2007, p. 27) and some sweets in her pocket. This description forms the starting-point for the analysis of the poem. It also paves the way for one to infer that the whole poem, as Naoot remarks, "is a reformative open letter written by Isis to warn the modern Egypt of dominating women" (Note 11) (2006, p. 11 [trans. mine]). For all the attractive appearance of Isis, she has no heart, mainly because the patriarchal power that marginalizes her replaces the heart with "a stone of fire". She wonders who will defend women's situation against the male aggression that evacuates history of the feminist enterprise: "who will tidy the bits of papers?" This question enables the reader to estimate that patriarchy does not only dehumanize women, but also forces them to suffer from spiritual loneliness, which forces them to hold that "smiling in sadness is an art/That honour in sadness is an art" (Naoot, 2007, p. 27). These two lines give rise to the birth of the new Isis whose greatness is not grounded in saving Osiris's corpse. Rather, it lies in receiving the male hegemony with a deep smile:

Isis

The slim one

Has a white dove on her head

Bags of sweets in her pocket

And a stone of fire

Instead of her heart. (Naoot, 2007, p. 27)

Although patriarchy is so harmful to women, it teaches women some lessons on affording the suffering of history. By having such lessons, the female develops a defence mechanism that helps woman refute the belief 
that they are the inessential other. Thus, Isis confirms that one way to shed man's power is to keep silent with a smile. This feminist reaction evinces that the poem does not offer the story of the mythic Isis. Instead, it "represents the voice of the recovering patriarchal Isis. It is a feminist powerful voice, which brings into play that feminist doctrine that resisting patriarchy relieves the tension and subjugation imposed on women by men" (Note 12) (Abd-al-Salam, 2007, p. 5 [trans. mine]). That is why Isis argues that silence and loneliness imbue her fabricated situation with "a sheath of grass/With three flowers" (Naoot, 2007, p. 27); each of which stands for a critical stage of the feminist struggle against the male domination. While the first flower tells of the tragic moments in which Osiris passed away leaving Isis alone, the second one refers to the birth of Horus, Isis's only child, whom she protects from the violence of the evil uncle Seth. Although she keeps an eye on Horus, she gets the feeling that he goes astray in the sky, motivating her to live in a total isolation. This isolation stems from her belief that Horus is "the jewels" that have been taken from her. Not only does his absence frustrate her, but it also sustains her silence:

It was a sheath of grass

With three flowers:

I kept the first for a hunting trip

A one-way trip

And the lover had left me.

My second flower

Was for a child

I fed him wheat from my palm

And he went astray in my sky. (Naoot, 2007, pp. 27-28)

The symbolic indication of the above-mentioned flowers brings out the significance of the third one. It also unfolds that "the power that man wields over woman can be related back to the patriarchal traditions that lends man a hand to subordinate all elements of existence including women who has no option but to submit to the higher authority of man" (Note 13) (Naoot, 2006, p. 11 [trans. mine]). The male approach to woman forces the latter to think of herself as "the bride of the Nile" (28) that throws herself into the river to rise again as "a lily in the Mediterranean" (Naoot, 2007, p. 28). By sacrificing herself, the woman deserves to be described as "a Romanian goddess", not a human being. This enables Isis to rebuild the power relationships between sexes by stepping "towards the spring" as if she were a rose waiting for the arrival of such a season to feel existence. That is why Naoot ends the poem with detailing the spiritual and physical features of the new Isis. This character relinquishes the brightness of gold and diamond in the hope of having "a golden bracelet on her wrist" and "a crown of light" on her head. In giving up such ornaments, which stand for the male power-mechanisms, Naoot asserts the sweeping victory of the female ideology over the male programming. This victory provides Isis with an eternal smile and fills her heart with a psychological relief, which verifies that her heart contains no pains, but "a whole galaxy":

And the third flower

The bride of the Nile

Dips herself in red to emerge,

a lily in the Mediterranean

I'm the slim Isis

No diamond on my finger

No golden bracelet on my wrist

But a crown of light on my head

A smile at my mouth

And in my heart

A whole galaxy. (Naoot, 2007, pp. 28-29)

The three flowers decorating Isis's sheath assert the triumph of women over the patriarchal programming that maintains the position of man as the essential subject and that of woman as the inessential other. This evil conception motivates Naoot to endow the new Isis with three flowers, which empowers the status of women as a 
wife, a mother, and the bride of the Nile. This feminist status category, particularly the image of Isis as the bride of the Nile that sacrifices her life for the good and fertility of the male and female, brings into play the sacrifice of Rich's Curie who dies of her scientific experiments. By quoting Beauvoir, one can infer that the conflict between the male and female can be traced back to the moment in which man "asserts himself as subject and freedom, the idea of the Other becomes mediatory. From this day on, the relationship with the Other is a drama" (2010, p. 113) that forces the male to oppress the female, mainly because she represents a threat and a danger to his fabricated existence. Such a male oppression motivates Naoot and Rich to hark back to history to create "Power" and "Isis" in the hope of contending that woman is not the inessential other. Rather, she is the essential subject, not a slave, or a thing. This implies that woman is not Pandora; rather, she is Isis and Curie.

\section{Conclusion}

Having examined Rich's “Aunt Jennifer's Tigers", “An Unsaid Word”, and "Power” and Naoot's "The Cock's Crest", "A Goose", and "Isis" in the light of Beauvoir and Millett's theory of patriarchy, I would like to conclude the following three remarks. Firstly, patriarchy refers to the power-structured relationships invented by the male to control and decentralize the female. This control gives rise to the birth of the male programming that draws on the patriarchal view that woman is nothing but a sexed being, or rather the inessential other. The inferior position of woman explains the reasons why women are associated with chaos and darkness, whereas men are identified with order and light. The association of the women with the negative aspects of human culture motivates all feminist critics including Rich and Naoot to set an aesthetic agenda for resisting the patriarchal programming, which sustains the male domination and the female subordination.

Secondly, a close reading to the poetry of Rich and Naoot evinces that even though both poets belong to two completely different cultural milieus, both are identical in incorporating Beauvoir and Millett's theory of patriarchy into their verse. The incorporation of such a theory enables both poets to constitute a poetic strategy in terms of which they portray how patriarch does not only segregate woman, but also beats her into holding that she is the eunuch other. However, each adopts a different poetic vision. Rich engineers a poetic vision which does not only assert the feminist thread of her poetry, but also contends that the power wielded by man over woman is not a natural phenomenon. Rather, it is the logical outcome of patriarchy, which permits man a complete authority to oppress woman by bringing on a tangle of oppressions. This assessment denotes that the male establishes the patriarchal codes to inflict serious exploitation, illegitimate control, slavery, and class domination upon the female. In order to shed such patriarchal paradigms, Rich develops a vision that unfolds the single causes that force man to claim superiority over woman as well as make the marginalization of woman on top priority of his agenda.

Unlike Rich who voices openly the feminist aspect of her poetry, Naoot refuses to be classified as a feminist poet. Her refusal can be traced back to her belief that art cannot be categorized on the ground of the sex of the artist for this classification deforms the philosophy of art. Despite that, the close reading to Naoot's poetry urges one to infer that she is a high-sounding feminist writer, simply because she utilizes her poetic talent to dramatize the power-structured relationships composed by man to marginalize woman as well as institutionalize the patriarchal creed that woman is the inessential other. Naoot levels a strong criticism at this male framework, inasmuch as it beats women into submission to the male hegemony. This submission flows from patriarchy that encourages man to establish himself as the essential subject and the woman as the inessential other. In a word, while Rich states overtly the feminist dimension of her poems, Naoot conceals the aesthetic essence of her poetry by rejecting the division of art according to the sex of the author.

Finally, in comparing Rich's "Aunt Jennifer's Tigers", “An Unsaid Word”, and "Power" with Naoot's "The Cock's Crest", "A Goose", and "Isis", one concludes that these pieces revolve around the systematized oppression of women. Such is the common theme of these poems in particular and Rich and Naoot's poetry in general. In "Aunt Jennifer's Tigers", Rich tackles the subordination and alienation that befall woman through the obligations of marriage. To clarify this painful experience, Rich uses Aunt Jennifer's tapestry of tigers as a defence mechanism in order to bridge the psychological gap caused by power-structured relationships that privilege the male over the female. That is, Aunt Jennifer's embroidery of tigers is a feminist battle cry against the male authority which is best represented through the appearance of the uncle, Aunt Jennifer's husband, whose memory devastates not only Jennifer's embroidery, but also her peace and purity. While the husband is the master, the Aunt is the slave, or rather the dominated that uses the art of tapestry to release herself from the power of the dominant. This male power leaves the female no alternative but to associate with the tigers in the hope of gaining their status category as effective subjects, not animals, or sexed things. 
In similar ways, the patriarchal power of man forces the protagonist of Naoot's "The Cock's Crest" to think of existence in terms of animal imagery, i.e., cat, butterfly, and cock. These images encourage the female to rebel against the male programming that subordinates women, as well as spoiling the tranquility of their existence. That is why, the poem entices women to relinquish the male-oriented societies and isolate themselves in a recovering patriarchal society where they can feel the bliss of solitude away from the segregation of man. In order to attract the attention of woman to the necessity of protesting against the male marginalization, Naoot repeats the following line more than once throughout the poem: "How nice." The repetition of this line reminds one of the "bright topaz" produced by Aunt Jennifer's embroidery. In brief, both Rich and Naoot draw extensively on animal imagery with a view to creating a female patriarchal society where there is no domination or subordination.

In "An Unsaid Word", Rich refutes the patriarchal view that the silent woman is the acceptable member of any society. This implies that man deploys the idea of marriage as a patriarchal instrument not only to assert his presence as a powerful oppressive character, but also to egg on the female to live within an estranged intensity. Thus, Rich strongly disapproves of the heroine's weak reaction to the hegemony of the husband for three reasons. First, she does not defend her feminist identity against the supremacy of man; second, instead of resisting man's power, she waits for the arrival of her husband to feel existence; lastly, the woman's silence fortifies the space of man as the essential subject and that of woman as the inessential other. These reasons refer one to figure out that the whole poem offers an unconditional surrender of woman to the patriarchal programming which ascertains that the male is the dominant who sets up the arrangements by which the female has no option but to act the part of the subordinate.

Unlike Rich's “An Unsaid Word”, Naoot's “A Goose” does not lament the silence of women. Rather, it projects a feminist voice that prefers silence rather than resistance. That is why Naoot depicts how man abuses the sacred bond of marriage to reinforce his patriarchal ideology on the female mentality. To crystallize this leitmotif, she delves deeply into the psyche of the track driver, the hero of the poem, in order to throw light on the hidden reasons that led him to behead the goose because of her sexual maturation. His behavior stems from the patriarchal notion that woman is a sexual being that has no function but to satisfy the sexual desires of man because he is the master who ought to be obeyed by the slave (the woman). For this reason, the poem rotates around the dogged determination of the man to control the woman: although the track driver resists slaughtering the goose, he beheads her by the end of the poem. This indicates that Rich and Naoot utilize the tragedy the befalls the two heroines of their poems with a view to demonstrating the oppression and subordination inflicted upon women's existence because of marriage that privileges one collectivity over another collectivity.

In "Power", Rich reconsiders the past in order to bring to light the sacrifice made by the French scientist Marie Curie who wins the Nobel Prize twice. This poetic motif helps Rich prove that history is a patriarchal discipline, mainly because man, who pictures women as if they had no past or history, wrote its codes. His very objective is to evacuate history from any female achievement. In examining history, Rich concludes that Curie was killed twice: first, she dies of radiation poisoning resulting from her scientific experiments; second, patriarchy assassinates her by effacing her name from the records of history. Hence, Rich retells the history of Curie who loses her sight and the ability to move her hands freely because she insists on working for the common good of humanity. The tragedy of Curie paves the way for Rich to warn the female that they should challenge man's authority, otherwise they will receive the painful fate of Curie. This statement compels one to elicit that one was not born a woman, but rather the male-oriented culture plays a decisive role in classifying people in terms of sex, not gender.

Similarly, Naoot harks back to the mythic history of Egypt to rework the story of Isis to reflect women's anxiety in a male-dominated discourse that glorifies the position of the female as a mother and wife. That is to say, Naoot creates a new Isis that receives the male hegemony with a deep silent smile, which endows her fabricated existence with three flowers; each of which stands for one of the prominent status categories assigned by patriarchy for woman: as a mother, a wife, and the bride of the Nile. In holding that the male domination transforms the female into the bride of the Nile, one can infer that Naoot adopts Rich's leitmotif of the victimization of women, which bestows a sort of eternity on the space of Isis and Curie. In this respect, Naoot's new Isis becomes a Romanian goddess, no to say Pandora that releases all the evils of humanity. This new Isis along with the three flowers decorating her sheath gives some indication of the sweeping victory of the female over the male - for these flowers sustain the situation of the former as the essential subject and the latter as the inessential other. In a word, both Rich and Naoot deploy their poetry to confute the patriarchal premise that woman is innately inferior to man. 


\section{References}

Abd-al-Salam, M. S. (2007). Taf al-'Onuthah al-Mustada: Qir'ah fi Haikal al-Zahr li Fatima Naoot. Al- $\underline{\text { Hiwar }}$ al-Mutamadn, 11 (July), 5.

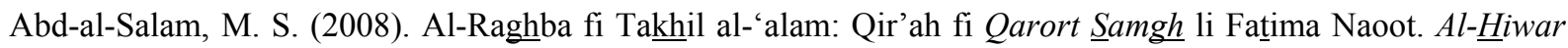
al-Mutamadn, 23(June), 7.

Beauvoir, S. D. (2010). The Second Sex (Constance Borde \& Sheila Malovany-Chevallier, Trans.). New York: Vintage.

Bloom, H. (2003). A Map of Misreading. New York: Oxford University Press.

Bryson, V. (2003). Feminist Political Theory: An Introduction. New York: Palgrave.

Budge, E. A. (1969). The God's of the Egyptians: Studies in Egyptian Mythologies. New York: Dovers Publication.

Butler, J. (1986). Sex and Gender in Simone de Beauvoir's Second Sex. Yale French Studies, 72, 35-49. https://doi.org/10.2307/2930225

Hassan, M., Kaur, H., \& Mani, M. (2016). A Symbolic Reading of Adrienne Rich's an Unsaid Word. International Letters of Social and Humanistic Sciences, 68, 55-60.

Heinama, S. (2005). Simone de Beauvoir's Phenomenology of Sexual Difference. Hypatia, 14(4), 114-132.

Jayasudha, P. (2016). A Feministic Perspective of the Selected Poems of Adrienne Rich. International Journal of English Research, 2(6), 49-50.

Millett, K. (1968). Sexual Politics: A Manifesto for Revolution. Radical Feminism, 365-367. https://doi.org/10.2307/20634474

Millett, K. (2000). Sexual Politics. Chicago: U of Illinois P.

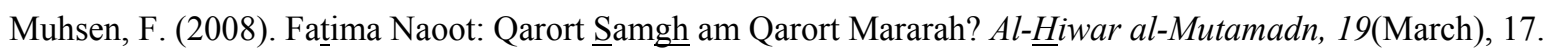

Naoot, F. (2003). Garidat al-Riadh Taltaqi al-Sha'rah Fatima Naoot. An Interview by Sami Hasson. Garidat al-Riadh, 11(July), 17.

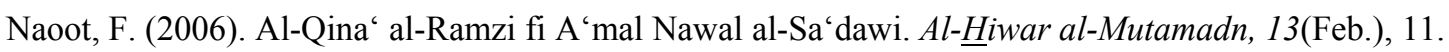

Naoot, F. (2007). A Bottle of Glue (Sayed Gouda, Trans.). London: Nadwah.

Naoot, F. (2008a). Qarort $\underline{\text { Samgh }}$. Al-Qahra: Dar Mirat.

Naoot, F. (2008b). Ghiab Gasad al-Ragul ka-Mawdo an Nas al-Sha'rah al-'Arabih. An Interview. al-Ghaoon, l(Azar), 8.

Naoot, F. (2009). Al-Mughani wa al-Haka: Qira't fi 'Amal Sha 'riah wa Sardiah. Cairo: Dar Akhbar al-Youm.

Plain, G., \& Sellers, S. (2007). A History of Feminist Literary Criticism. New York: Cambridge University Press.

Prace, B. (2009). Poetry of Adrienne Rich: The Sources of Female Power (Unpublished doctoral dissertation). Prague University, Prague, Czech.

Rich, A. (1972). When We Dead Awaken: Writing as Re-Vision. College English: Women, Writing, and Teaching, 34(1), 18-30.

Rich, A. (1986). Blood, Bread and Poetry: Selected Prose, 1979-1986. New York: Norton.

Rich, A. (2002). The Fact of a Doorframe: Poems Selected and New, 1950-1984. New York: Norton.

Rogan, A. (2002). The Future in Feminism: Reading Strategies for Feminist Theory and Science Fiction. Doctoral dissertation, Louisiana State University, America. https://doi.org/10.1632/003081204x20226

Scott, J. (1990). Domination and the Arts of Resistance: Hidden Transcripts. London: Yale University Press.

Soghra, N., \& Pourgiv, F. (2016). On the Development of Female Voice in Adrienne Rich. Studia: Philologia, $21,71-82$.

Stein, K. (2017). Adrienne Rich: Challenging Authors. Boston: Sense.

Thurman, J. (2010). Introduction. In S. D. Beauvoir (Ed.), The Second Sex (pp. 8-15). New York: Vintage.

Tyson, L. (2006). Critical Theory Today: A User-Friendly Guide. London: Rutledge. 


\section{Notes}

All translations from Arabic are mine.

1- المر أة إنسان، و الكتابة تجربة إنسانية ،إذن الكتابة التي تكتبها المر أة هي تجربة إنسانية، تنطلق من المؤرقات نفسها التي تدفع الرجل إلى الكت الكتابة.

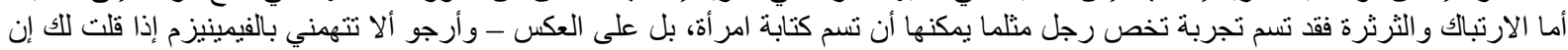
عقل المر أة أكثر تتظيما من عقل الرجل.

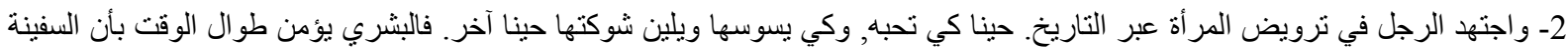

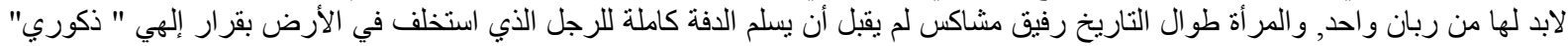

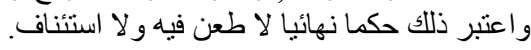

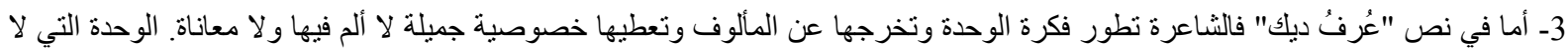

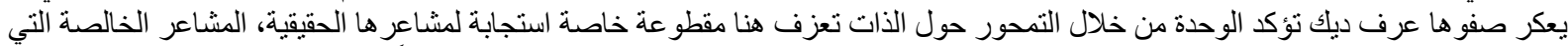
لا يشوبها نظرة المجتمع للمر أة الوحيدة ليز احمو ها بأفكار هم (كظل رجل ولئ ولا ظل حيطة) تعيش حياتها بعيداً عن عقل الآخر وروحه وتنغيصاته الأخرى التي يضيفها على الحياة.

4- وفي "عرف ديك" تتشكل تجربة الأنوثة فيما ترك الذكر من فر اغ، يصلح لاستبدال أنثوي مملوء بتأملات خاصة، هي تضاعف لأنس للأنثى، من داخل رسم حدودها الثخصية الجديدة خارج الهيمنة: تصنئ

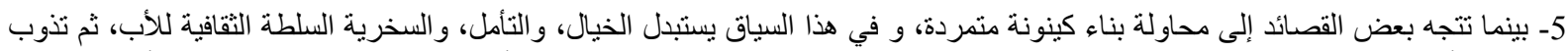

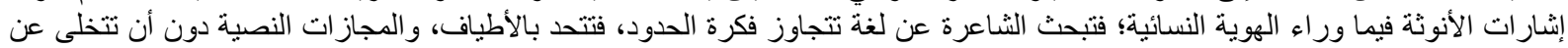

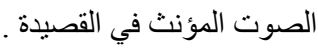
6- بطريركية المر أة

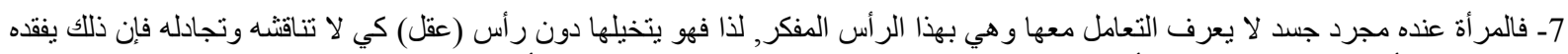

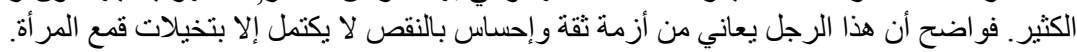

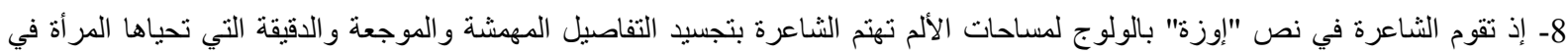
المجتمعات الذكورية المتسلطة.

9ـ الإوزة تستنف حدث الذبح في تجاوز تجربة الدم برمتها، فتضع القاتل في مواجهة مع تجسده المحدود المقاوم لثاعرية الوجود الكوني.

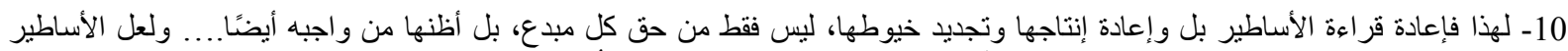

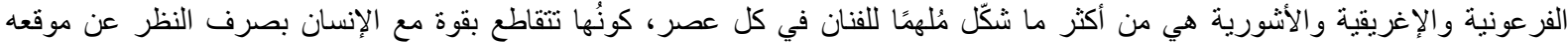

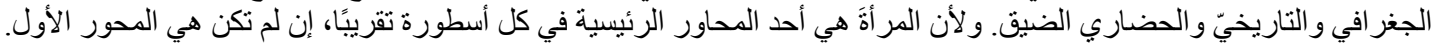

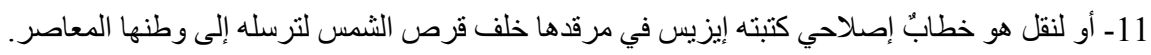

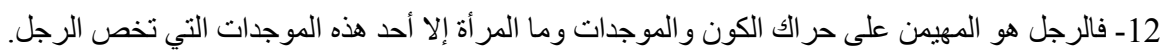

\section{Appendix A}

\section{Transliteration System}

\begin{tabular}{|c|c|c|c|}
\hline Description & Transliteration & Name & Letter \\
\hline voiced bilabial stop & $/ \mathrm{b} /$ & ba & ب \\
\hline voiceless alveolar stop & $/ \mathrm{t} /$ & ta & $ت$ \\
\hline voiceless dental fricative & /th/ & sa & $ث$ \\
\hline voiced palato-alveolar affricative & $/ \mathrm{j} /$ & jim & 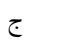 \\
\hline voiceless pharyngeal fricative & $/ \underline{\mathrm{h}} /$ & ha & $\tau$ \\
\hline voiceless uvular fricative & $/ \underline{\mathrm{kh}} /$ & kha & $\dot{\tau}$ \\
\hline voiced alveolar stop & $/ \mathrm{d} /$ & dal & د \\
\hline voiced dental fricative & $/ \underline{\mathrm{d}} /$ & zal & ذ \\
\hline voiced alveolar roll & $/ \mathrm{r} /$ & ra & J \\
\hline voiced alveolar fricative & $|z|$ & $\mathrm{za}$ & j \\
\hline voiceless alveolar fricative & $/ \mathrm{s} /$ & $\sin$ & 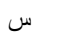 \\
\hline voiceless palato-alveolar fricative & $/ \underline{\mathrm{sh}} /$ & $\operatorname{shin}$ & 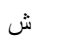 \\
\hline voiceless alveolar fricative & $/ \underline{s} /$ & sad & ص ص la la \\
\hline voiced alveolar stop & $/ \underline{\mathrm{dh}} /$ & dad & 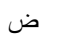 \\
\hline voiceless alveolar stop & $/ \underline{t} /$ & ta & $b$ \\
\hline voiced dental fricative & /Z/ & $\mathrm{za}$ & ظ \\
\hline voiceless pharyngeal fricative & $1 \%$ & ain & $\varepsilon$ \\
\hline voiced uvular fricative & $/ \mathrm{gh} /$ & ghain & $\dot{\varepsilon}$ \\
\hline voiceless labio-dental fricative & $/ \mathrm{f} /$ & $\mathrm{fa}$ & ف \\
\hline voiceless uvular stop & $/ \mathrm{q} /$ & qaf & ق \\
\hline
\end{tabular}




\begin{tabular}{|c|c|c|c|}
\hline voiceless velar stop & $/ \mathrm{k} /$ & kaf & ك5 \\
\hline voiced alveolar lateral & /1/ & lam & 」 \\
\hline voiced bilabial nasal & $/ \mathrm{m} /$ & $\operatorname{mim}$ & s \\
\hline voiced alveolar nasal & $/ \mathrm{n} /$ & nun & ن \\
\hline voiceless glottal fricative & $/ \mathrm{h} /$ & ha & هـ \\
\hline voiced bilabial semi-vowel & $/ \mathrm{w} /$ & waw & g \\
\hline voiced palatal semi-vowel & $/ \mathrm{y} /$ & ya & ى \\
\hline voiced glottal stop & I' & alif & ع (همزة) \\
\hline \multicolumn{4}{|l|}{ Vowels } \\
\hline front open short & $/ \mathrm{a} /$ & & --- \\
\hline front close short & /i/ & & - \\
\hline back close short & $/ \mathrm{u} /$ & & --_-- \\
\hline
\end{tabular}

\section{Copyrights}

Copyright for this article is retained by the author(s), with first publication rights granted to the journal.

This is an open-access article distributed under the terms and conditions of the Creative Commons Attribution license (http://creativecommons.org/licenses/by/4.0/). 